\title{
REVERSAL OF LIPAEMIA RETINALIS WITH DIETARY CONTROL
}

\author{
JAGAT RAM $^{1}$, S. S. PANDAV ${ }^{1}$, SANDEEP JAIN ${ }^{1}$, SUNIL ARORA ${ }^{2}$, AMOD GUPTA $^{1}$ \\ and ASHOK SHARMA ${ }^{1}$ \\ Chandigarh, India
}

\begin{abstract}
SUMMARY
Lipaemia retinalis occurs as the result of a marked elevation of serum lipids. Combined hyperlipidaemia may occur as a primary familial or secondary acquired abnormality. A case of lipaemia retinalis is described, documented by fundus photographs. A complete lipid profile of the patient revealed marked hyperlipidaemia. The lipoprotein lipase level was found to be reduced $0.3 \mathrm{cu}$ (normal 0.5-2.0 cu). The patient was put on a lowfat diet, after which serial fundus photographs showed an improvement in the fundus appearance. Follow-up lipid profile estimations showed a decrease in triglyceride and cholesterol levels. After 6 months of follow-up complete reversal of lipaemia retinalis was documented. In this case, reversal of lipaemia retinalis occurred with dietary therapy alone.
\end{abstract}

Lipaemia retinalis, first described by Heyl ${ }^{1}$ in 1880 , occurs as a result of a marked elevation in serum lipid levels. Hyperlipidaemia may occur as a result of primary familial or secondary acquired abnormality. ${ }^{2}$ Systemic disorders, diabetes mellitus, hypothyroidism, nephrotic syndrome, biliary obstruction and alcoholism may lead to secondary hyperlipidaemia. ${ }^{2}$ This report describes a case of lipaemia retinalis with primary hyperlipidaemia, and documents the complete reversal of the lipaemia retinalis with a lowfat diet alone.

\section{CASE REPORT}

A 16-year-old male with a diagnosis of hyperlipidaemia was referred for an ophthalmological examination. The patient had no ocular complaints. His visual acuity was 20/20 in both eyes. Results of slip lamp biomicroscopy were unremarkable. Intraocular pressure was $12 \mathrm{mmHg}$ in both eyes. On fundus examination the retinal vessels had a

From: Departments of 'Ophthalmology and ${ }^{2}$ Biochemistry, Postgraduate Institute of Medical Education and Research, Chandigarh, India.

Correspondence to: Dr Jagat Ram, Department of Ophthalmology, Postgraduate Institute of Medical Education and Research, Chandigarh-160012, India. milky-white appearance and the retinal background showed a diffuse milky hue in both eyes. The optic discs were normal. Retinal arterioles could be differentiated from veins only by the larger calibre of the venules (Fig. 1). Fundus fluorescein angiography did not show any abnormality. Visual field evaluation on automated perimeter (Topcon) revealed normal fields. Systemic examination revealed marked pallor of the skin, moderate hepatosplenomegaly and hypogonadism. The patient had not received any systemic medication prior to detection of hyperlipidaemia. The patient was not a vegetarian and used to take more than two eggs per day, butter, saturated fats and cream in plenty.

A haemogram revealed a total leucocyte count of $11.5 \times 10^{6} / 1$ and a differential leucocyte count of polymorphs $41 \%$, lymphocytes $57 \%$, eosinophils $2 \%$. Haemoglobin estimation was difficult as the blood was milky white; subsequently it was found to be $12 \mathrm{~g} / \mathrm{dl}$. The platelet count was $1.7 \times 10^{8} / 1$. A serum lipid profile revealed triglycerides $>12000 \mathrm{mg} / \mathrm{dl}$, cholesterol $3400 \mathrm{mg} / \mathrm{dl}$, phospholipids $2911 \mathrm{mg} / \mathrm{dl}$ and high density lipoproteins (HDL) $76 \mathrm{mg} / \mathrm{dl}$. The lipoprotein lipase level was $0.3 \mathrm{cu}$ (normal 0.5-2.0 cu). Chromosomal studies of the patient revealed a normal pattern. A lipid profile of the patient's younger sister showed a mild elevation of serum triglycerides and cholesterol (Table I). Other biochemical investigations revealed fasting and post-prandial blood sugar levels of $63 \mathrm{mg} / \mathrm{dl}$ and $75 \mathrm{mg} / \mathrm{dl}$, respectively, blood urea $28 \mathrm{mg} / \mathrm{dl}$, bilirubin $0.5 \mathrm{mg} / \mathrm{dl}$ serum glutamic-oxaloacetic transaminase (SGOT) 7 units, serum glutamicpyruvic transaminase (SGPT) 7 units and alkaline phosphatase 6.0 units. Thyroid functions showed the serum $T_{4}$

Table I. Lipid profile of the patient's parents and siblings

\begin{tabular}{lccccc}
\hline $\begin{array}{l}\text { Family } \\
\text { members }\end{array}$ & $\begin{array}{c}\text { Age } \\
(\mathrm{yr})\end{array}$ & $\begin{array}{c}\text { Triglyceride } \\
(\mathrm{mg} / \mathrm{dl})\end{array}$ & $\begin{array}{c}\text { Total } \\
\text { cholesterol } \\
(\mathrm{mg} / \mathrm{dl})\end{array}$ & $\begin{array}{c}\text { Phospholipid } \\
(\mathrm{mg} / \mathrm{dl})\end{array}$ & $\begin{array}{c}\text { HDL } \\
(\mathrm{mg} / \mathrm{dl})\end{array}$ \\
\hline Father & 50 & 230 & 245 & 135 & 80 \\
Mother & 42 & 219 & 235 & 105 & 76 \\
Brother & 13 & 195 & 213 & 90 & 78 \\
Sister & 11 & 276 & 296 & 120 & 74 \\
\hline
\end{tabular}




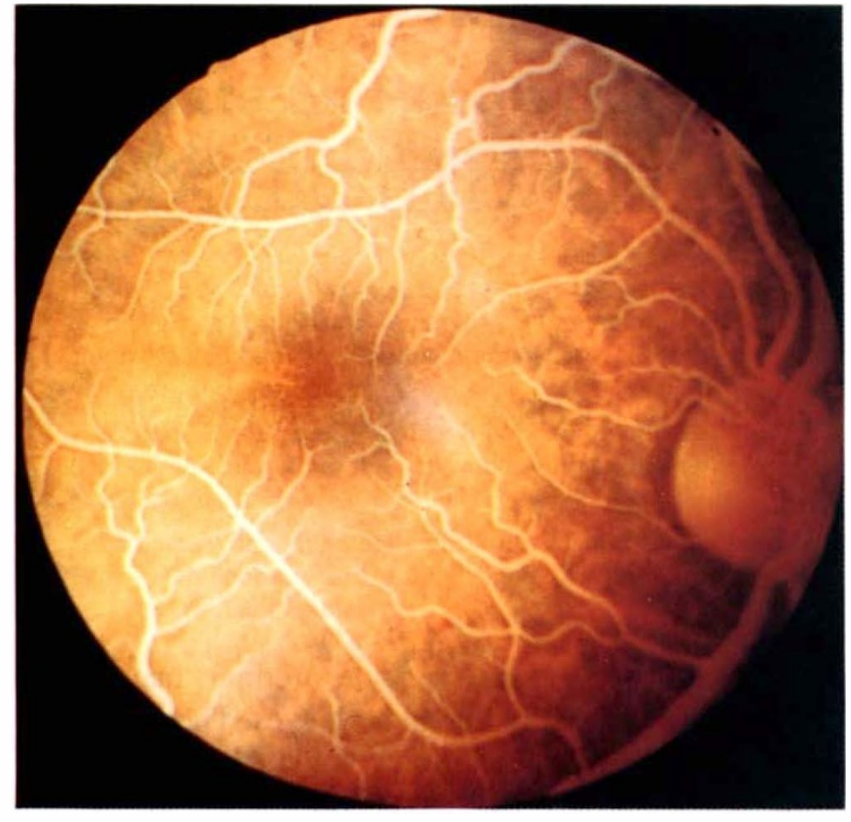

(a)

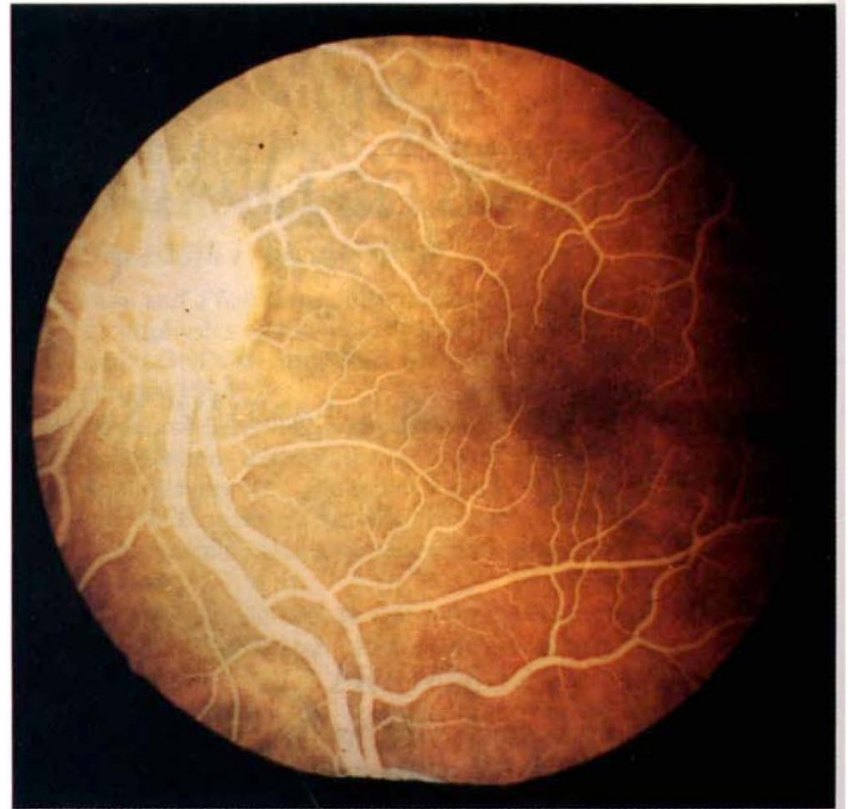

(b)

Fig. 1. Milky white appearance of the retinal blood vessels in lipaemia retinalis. (a) Right eye; (b) left eye.

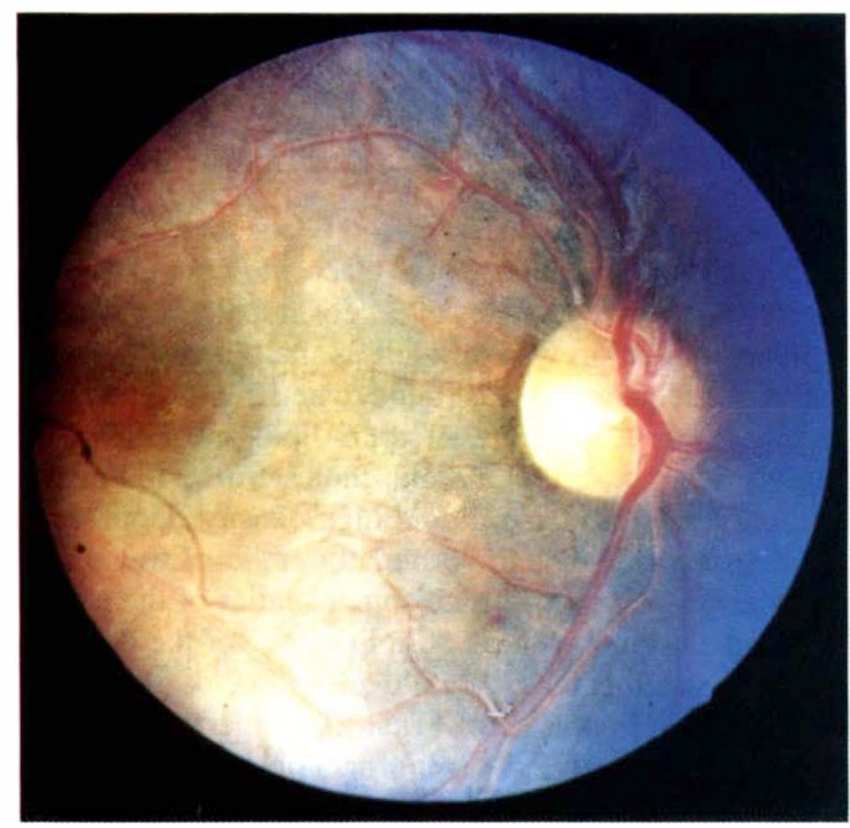

(a)

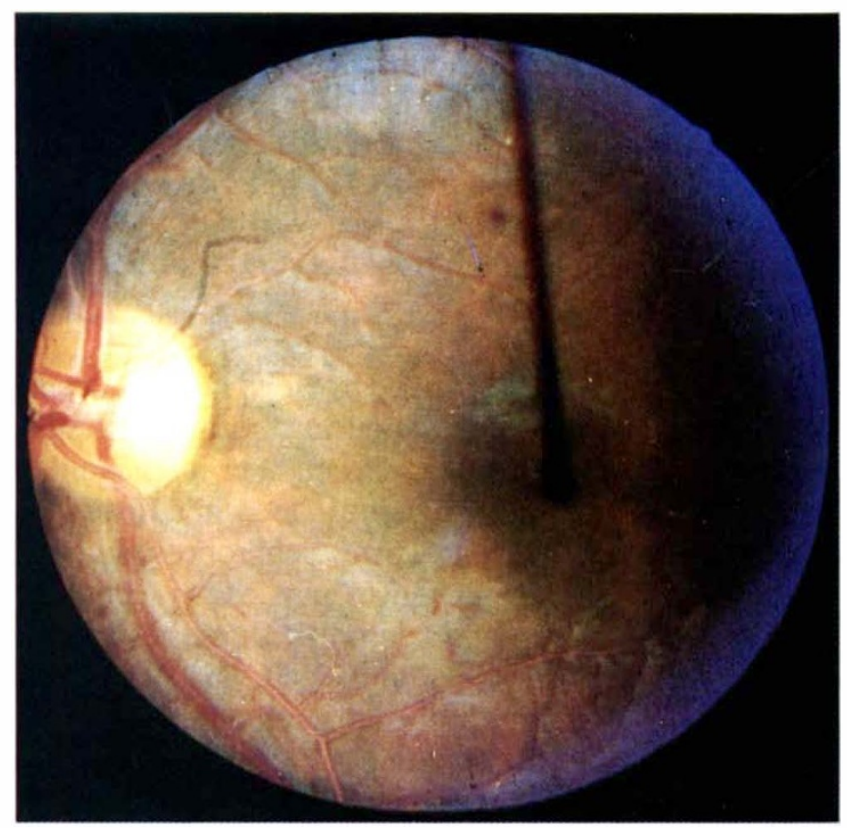

(h)

Fig. 2. Normal appearance of the retinal blood vessels after following a fat-free diet. (a) Right eye; (b) left eye.

to be $6 \mu \mathrm{g} / \mathrm{dl}$ and serum $\mathrm{T}_{3} 110 \mu \mathrm{g} / \mathrm{dl}$. A diagnosis of lipaemia retinalis with primary hyperlipidaemia was made. The patient was put on a low-fat diet and advised against taking eggs, butter, ghee (Indian clarified butter made from the milk of buffalo or cow) and cream. It took nearly 4 months for the patient to change his eating habits.

Results of follow-up laboratory examination showed a continuous fall in serum triglyceride and cholesterol levels (Table II). Follow-up examination showed an improvement in the fundus appearance. Six months later, fundus examination showed a complete reversal of the retinal changes (Fig. 2). A repeat serum lipid estimation at this time revealed that triglycerides had fallen to $1396 \mathrm{mg} / \mathrm{dl}$ and cholesterol to $690 \mathrm{mg} / \mathrm{dl}$.

\section{DISCUSSION}

Hyperlipidaemia is the excessive accumulation of one or more of the major lipids (triglycerides and cholesterol). ${ }^{3}$ For unexplained reasons, some individuals with marked hyperlipidaemia have no symptoms or signs. ${ }^{4}$ More commonly individuals develop eruptive xanthomas, lipaemia retinalis, recent memory loss and pancreatitis. ${ }^{5}$ Our patient 
Table II. Serial lipid profile of the patient

\begin{tabular}{lcccc}
\hline & $\begin{array}{c}\text { Triglyceride } \\
(55-285)^{\mathrm{a}}\end{array}$ & $\begin{array}{c}\text { Total cholesterol } \\
(140-265)\end{array}$ & $\begin{array}{c}\text { Phospholipid } \\
(150-250)\end{array}$ & $\begin{array}{c}\text { HDL } \\
(30-90)\end{array}$ \\
\hline At presentation & $>12000$ & 3400 & 2911 & 76 \\
Follow-up, 6 weeks & 11000 & 2711 & 2773 & 74 \\
Follow-up, 6 months & 1396 & 690 & 1174 & 74 \\
\hline
\end{tabular}

All values are in $\mathrm{mg} / \mathrm{dl}$.

${ }^{a}$ Values in parentheses are the normal range.

had lipaemia retinalis and hepatosplenomegaly in association with marked hypertriglyceridaemia and hypercholesterolaemia. His younger sister also showed a mild elevation of serum cholesterol and triglycerides. In a recent report, a case of lipaemia retinalis due to secondary hyperlipidaemia in diabetes mellitus has been reported. ${ }^{6}$ However, our patient did not suffer from diabetes mellitus, nephrotic syndrome, hypothyroidism, biliary obstruction or alcoholism. In addition he had not received any drugs in the recent past. A high intake of dietary fats alone does not lead to persistent hyperlipidaemia. In our patient lipoprotein lipase deficiency coupled with a high intake of dietary fats was responsible for the hyperlipidaemia.

Lipaemia retinalis becomes evident on fundus examination if plasma triglyceride levels are greater than $2500 \mathrm{mg} \%{ }^{2}$ Mild hyperlipidaemia causes changes in the thinner peripheral retinal vessels whereas marked hyperlipidaemia leads to changes in the central retinal vessels also. ${ }^{6}$ In our patient, due to massive hyperlipidaemia the arterioles and venules appeared uniformly white in colour and could be distinguished only by calibre. The retinal background showed a milky hue from marked hyperlipidaemia in the choroidal circulation.

In lipaemia retinalis visual acuity is not affected. ${ }^{6}$ Recognition of hyperlipidaemia and early institution of therapy is vital to avoid systemic complications such as pancreatitis and accelerated atherosclerotic disease. ${ }^{6}$ Therapy in this disorder is directed towards avoiding fatcontaining foods and restricting fat intake to less than $20 \mathrm{~g}$ per day. ${ }^{5}$ In our case reversal of lipaemia retinalis occurred as a result of dietary therapy alone.

Key words: Diet control, Fundus, Lipaemia retinalis, Reversal, Serum lipids.

\section{REFERENCES}

1. Heyl AG. Intraocular lipaemia. Trans Am Ophthalmol Soc 1880;3:55

2. Brown M, Goldstein J. The hyperlipoproteinemias and other disorders of lipid metabolism. In: Braunwald E, Isselbacher KJ, Petersdorf RG, Nilson JD, Martin JB, Fauci AS, editors. Harrison's principles of internal medicine. 11th ed. New York: McGraw-Hill, 1987:1650-61.

3. Barchiesi BJ, Eckel RH, Ellis PP. The cornea and disorders of lipid metabolism. Surv Ophthalmol 1991;36:1-22.

4. Duke-Elder S. System of ophthalmology. Diseases of retina, vol X, St Louis: Mosby, 1967:452-3.

5. Brunzell JD, Bierman EL. Chylomicronemia syndrome: interaction of genetic and acquired hypertriglyceridemia. Med Clin North Am 1982;66:455-68.

6. Martinez KR, Cibis GW, Tauber JT. Lipaemia retinalis. Arch Ophthalmol 1992;110:1171. 